\title{
En bedre screeningtest for prostatakreft?
}

En ny screeningmetode for prostatakreft har vist bedre resultater enn test for kun prostataspesifikt antigen.

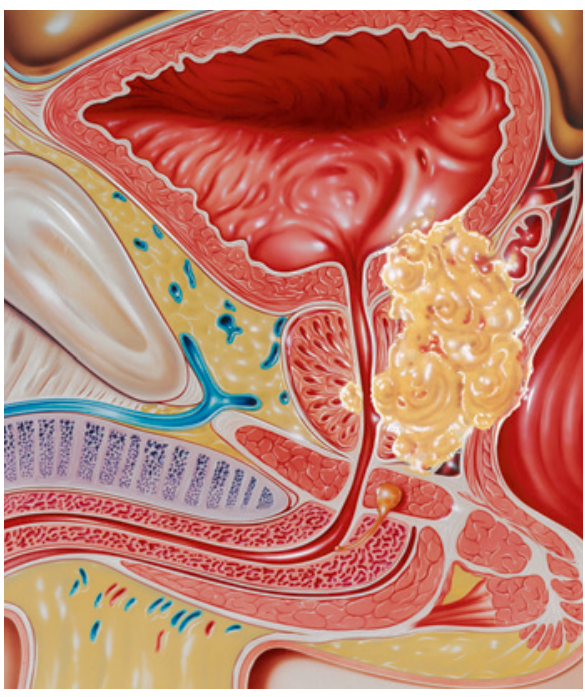

Illustrasjonsfoto: Science Photo Library
I en svensk studie ble rundt 59000 menn i alderen 50-69 år undersøkt for prostataspesifikt antigen (PSA) og en kombinasjon av biomarkører i plasma, genetikkprøver og anamnestiske variabler, omtalt som STHLM3-testen (1). Testenes sensitivitet ble definert som oppdagelsen av høyrisikoforandringer ved prostatabiopsi, og testenes spesifisitet ble definert som andelen biopsier med positive funn.

STHLM3-testen viste signifikant bedre resultater enn PSA-testen alene for oppdagelse av høyrisikoforandringer. Av 603 pasienter med høyrisikoforandringer, dvs. Gleason-skår $\geq 7$, hadde $124(21 \%)$ et PSAnivå på $1-3$. PSA-måling alene ville $\mathrm{i}$ de fleste tilfeller ikke ført til biopsi hos disse pasientene. Sammenlignet med PSA-nivå $>3$ oppdaget STHLM3-testen like mange menn med høyrisikoforandringer ved prostatabiopsi, men med $32 \%$ (95\% KI 24-39) færre biopsier. Andel negative biopsier ble redusert med $44 \%$ (95\% KI 35-54).

- Det er et viktig mål ved diagnostikk av prostatakreft å redusere andelen menn som må utføre en prostatabiopsi, sier Christoph
Müller, som er overlege ved Sørlandet sykehus. - STHLM3-testen er en pragmatisk test som kombinerer plasmamarkører og anamnestiske og kliniske variabler. Studien har svært mange deltakere og dokumenterer at testen har høyere deteksjonsrate av høyrisikokreft og lavere unødvendig biopsirate, sier han.

- Denne studien vil sannsynligvis ikke føre til at STHLM3-testen vil bli anbefalt for populasjonsbasert screening. Selv om den har ført til redusert andel negative biopsier og andel med prostatakreft med lav risiko, har man fortsatt ikke løst problemet med overdiagnostikk. Det pågår for tiden flere studier for å se nøyaktig hvilken rolle STHLM3-testen kan og bør ha, sier Müller.

\section{Kaveh Rashidi}

Tidsskriftet

\section{Litteratur}

1. Grönberg $\mathrm{H}$, Adolfsson J, Aly M et al. Prostate cancer screening in men aged $50-69$ years (STHLM3): a prospective population-based diagnostic study. Lancet Oncol 2015; 16: 1667-76.

\section{Akuttmedisinske team redder liv}

\section{Akuttmedisinske utrykningsteam på sykehus er assosiert med redusert dødelighet, færre tilfeller av hjertestans og færre innleggelser på inten- sivavdeling, viser ny studie.}

Pasienter som får hjertestans eller på andre måter trenger intensivmedisinsk behandling mens de er innlagt på sykehus, har ofte klinisk forverring i timene før hendelsen. Av den grunn har flere sykehus både $\mathrm{i}$ utlandet og Norge innført akuttmedisinske utrykningsteam som rykker ut til pasienten når bestemte kriterier er oppfylt.

I en nylig publisert studie ble slike akuttmedisinske utrykningsteam ved 12 nederlandske sykehus evaluert rundt ett år etter at ordningen ble innført (1). Studien omfattet rundt 167000 medisinske og kirurgiske pasienter. Sykepleiere og leger brukte skåringssystemer for å vurdere pasientenes vitale tegn og om det var behov for varsling av utrykningsteam, som besto av intensivsykepleier og lege med akuttmedisinsk erfaring.

Antall hjertestans, overflyttinger til intensivavdeling og dødsfall per 1000 innleggelser ble signifikant redusert etter oppstart av utrykningsteam sammenliknet med tiden før, med justert oddsratio på $0,85(95 \% \mathrm{KI}$ 0,73-0,99).

- Dette er en stor og godt gjennomført studie, med interessante og oppmuntrende resul- tater for oss som allerede har innført utrykningsteam på sykehuset, sier Peter Holm, overlege på Intensivavdelingen ved Sykehuset Østfold. - Vår erfaring viser at opplæring er svært viktig ved innføring av skåringssystemer, slik at leger og sykepleiere på post føler eierskap til systemet. Et utrykningsteam må ikke bli et «skalkeskjul» for lav sykepleiebemanning på sengepostene, og avdelingens ansvarlige lege må delta ved tilsyn fra teamet.

- Denne studien viser ikke bare at akuttmedisinske team kan redde liv, men også at det kan føre til færre uhensiktsmessige gjenopplivingsforsøk. Noen utrykninger fører til en helhetsvurdering om at pasienten ikke vil profittere på gjenoppliving eller annen intensivbehandling, sier Holm.

\section{Liv-Ellen Vangsnes}

Tidsskriftet

\section{Litteratur}

1. Ludikhuize J, Brunsveld-Reinders AH, Dijkgraaf MGW et al. Outcomes Associated With the Nationwide Introduction of Rapid Response Systems in The Netherlands. Crit Care Med 2015; 43 2544-51.

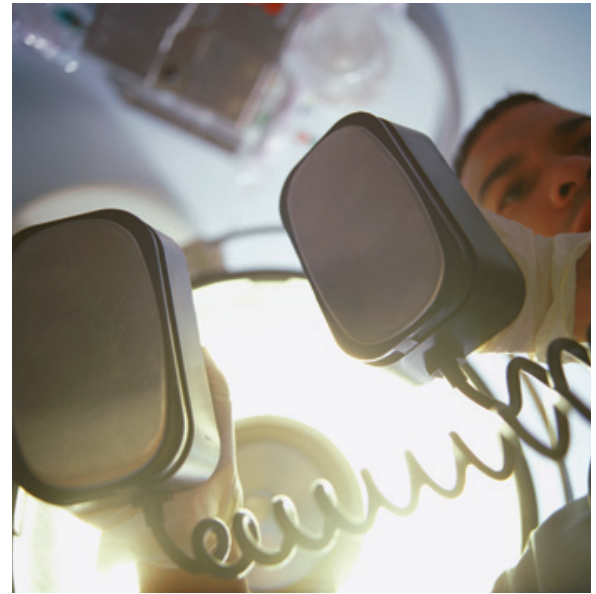

Illustrasjonsfoto: Thinkstock 